\title{
UPAYA MENINGKATKAN MINAT DAN HASIL BELAJAR SISWA DALAM PEMBELAJARAN MATEMATIKA MATERI PEMBULATAN BILANGAN MELALUI MODEL PEMBELAJARAN DEMONSTRASI KELAS IV SD NEGERI 3 PURWOJATI TAHUN PELAJARAN 2013/ 2014
}

\author{
Oleh: \\ Mistam \\ SD Negeri 3 Purwojati
}

\begin{abstract}
ABSTRAK
Berdasarkan hasil observasi kondisi awal sebelum penelitian tindakan kelas minat dan hasil belajar banyak yang belum memenuhi kriteria ketuntasan minimal, siswa belum paham tentang pembulatan bilangan sehingga siswa banyak yang belum minat dalam pembelajaran matematika. Tujuan penelitian ini adalah untuk meningkatkan minat dan prestasi belajar matematika materi pembulatan bilangan bagi siswa kelas IV SD Negeri 3 Purwojati Semester I Tahun Pelajaran 2014 / 2015 melalui model pembelajaran Demonstrasi. Penelitian ini dilaksanakan pada minggu kedua bulan September sampai minggu ketiga bulan September 2014 bertempat di SD Negeri 3 Purwojati. Adapun yang digunakan sebagai subyek penelitian adalah siswa kelas IV SD Negeri 3 Purwojati dengan jumlah siswa sebanyak 18 siswa yang terdiri dari 7 siswa laki-laki dan 11 siswa perempuan.

Penelitian dilakukan dengan menggunakan metode penelitian tindakan kelas dengan pendekatan model pembelajaran Demonstrasi yang terdiri dari dua siklus dan tiap siklus terdiri dari empat tahapan yaitu (1) Perencanaan tindakan, (2) Pelaksanaan tindakan, (3) Pengamatan, dan (4) Refleksi. Siklus I menggunakan model pembelajaran Demonstrasi dalam kelompok besar, pada siklus II menggunakan model pembelajaran Demonstrasi dengan kelompok kecil. Pada siklus II diketahui telah terjadi peningkatan rata-rata kelas dari kondisi studi awal rata-rata ulangan harian. Tes siklus I rata-rata 50,8 dan siklus II rata-rata 77,22. Sedangkan ketuntasan belajar siswa ada peningkatan dari kondisi studi awal yang sudah tuntas pada ulangan harian adalah 4 siswa. Siklus I yang tuntas 4 siswa dan pada akhir siklus II yang tuntas 18 siswa dari jumlah 18 siswa. Dengan demikian sebagian besar siswa kelas IV SD N 3 Purwojati mengalami peningkatan hasil belajar.
\end{abstract}

Kata kunci : Metode pembelajaran demonstrasi, Minat dan, Hasil belajar

\section{Pendahuluan}

Pada tahun pelajaran 2014/2015 saya ditugaskan mengajar kelas IV di SD Negeri 3 Purwojati Kecamatan Purwojati, Kabupaten Banyumas. Pada pelajaran matematika, kesulitan untuk mencari metode atau model pembelajaran apa yang cocok dengan pembelajaran yang akan diajarkan. Materi ini kadang juga bingung untuk menentukan model pembelajaran dan alat peraganya? Pemilihan model pembelajaran peserta didik Sekolah Dasar kalau tidak memperhatikan karakteristik perkembangan peserta didik SD maka pembelajaran tidak akan berhasil. Hasil belajar matematika pada materi pembulatan bilangan masih rendah karena banyak nilai peserta didik di bawah kriteria ketuntasan minimal. Untuk mengatasi masalah 
tersebut maka diadakan penelitian tindakan kelas. Melalui model Demonstrasi bagi peserta didik kelas IV SD Negeri 3 Purwojati Semester I Tahun Pelajaran 2014 / 2015 diharapkan dapat meningkatkan minat dan hasil belajar matematika pada materi pembulatan bilangan, karena jika masalah ini tidak cepat-cepat diatasi akan menimbulkan berbagai masalah yang dapat merugikan peserta didik tersebut dan semua pihak yang terkait khususnya dunia pendidikan.

Hasil nilai ulangan harian mata pelajaran matematika kompetensi dasar melakukan pembulatan bilangan belum mencapai kriteria ketuntasan minimal maka perlu dicari cara penyelesaiannya agar hasil belajar meningkat. Penelitian tindakan kelas ini diharapkan dapat memperbaiki hasil belajar peserta didik. Berdasarkan latar belakang masalah tersebut diharapkan dapat menjawab :

1. Bagaimana proses penerapan model pembelajaran Demonstrasi yang dapat meningkatkan hasil belajar peserta didik SD Negeri 3 Purwojati?

2. Bagaimana peningkatan hasil belajar peserta didik SD Negeri 3 Purwojati setelah diterapkan model pembelajaran Demonstrasi pada materi pembulatan bilangan ?

Adapun tujuan dalam penelitian ini adalah:

a. Untuk meningkatkan pemahaman mata pelajaran matematika materi pembulatan bilangan.

b. Untuk meningkatkan hasil belajar mata pelajaran matematika materi pembulatan bilangan.

c. Melalui model pembelajaran Demonstrasi untuk meningkatkan pemahaman mata pelajaran matematika materi pembulatan bilangan bagi peserta didik kelas IV SD Negeri 3 Purwojati semester I tahun pelajaran 2014/2015.

d. Melalui model pembelajaran Demonstrasi untuk meningkatkan hasil belajar mata pelajaran matematika materi pembulatan bilangan bagi peserta didik kelas IV SD Negeri 3 Purwojati semester I tahun pelajaran 2014/2015.

\section{Kerangka Teori}

Metode Pembelajaran Demonstrasi adalah metode mengajar dengan cara memperagakan barang, kejadian, aturan dan urutan melakukan kegiatan, baik secara langsung maupun melalui penggunaan media pengajaran yang relevan dengan pokok bahasan atau materi yang sedang disajikan. Minat adalah gejala psikologis yang menunjukan bahwa minat adanya pengertian subyek terhadap obyek yang menjadi sasaran karena obyek tersebut menarik perhatian dan menimbulkan perasaan senang sehingga cenderung kepada obyek tersebut. 
Dari hasil nilai ulangan harian materi pembulatan bilangan semester I yang nilainya rata-rata masih di bawah kriteria ketuntasan minimal maka perlu adanya tindakan perbaikan agar peserta didik kelas IV SD Negeri 3 Purwojati nilai-nilai matematika dapat ditingkatkan minimal nilai rata-rata kelas sama dengan kriteria ketuntasan minimal kelas IV SD Negeri 3 Purwojati. Peserta didik mendapatkan nilai rendah disebabkan oleh berbagai faktor, misalnya saja peserta didik belum paham tentang materi pembulatan bilangan, kurang banyak latihan soal-soal matematika, anak kurang aktif dalam mengikuti pelajaran matematika dan tidak mau bertanya walaupun belum paham. Bila ini tidak cepat-cepat diatasi maka nilai peserta didik akan terus merosot dan merugikan peserta didik itu sendiri.

\section{Metode Penelitian}

\section{Prosedur Pelaksanaan Penelitian Tindakan Kelas}

Menurut Wardani (2003:24) mengatakan bahwa langkah-langkah Penelitian Tindakan Kelas, yaitu melalui pengkajian berdaur yang terdiri dari 4 tahap, merencanakan (planning), tindakan (acting), pengamatan (observing), dan refleksi (reflection). Dari tiap-tiap siklus dilaksanakan sesuai dengan rencana pembelajaran yang telah disusun dan tidak lepas dari saran Kepala Madrasah, Pembimbing, maupun teman peneliti yang lain. Pelaksanaan siklus ini berlangsung dalam 2 kali tahap perbaikan. Masalah baru yang timbul akan dipecahkan kembali melalui daur PTK. Prosedur perbaikan pembelajaran dirancang dalam urutan tahap sebagai berikut :

a. Mengidentifikasikan masalah, menganalisis, merumuskan masalah, dan merumuskan hipotesis.

b. Menemukan cara pemecahan masalah/ tindakan perbaikan.

c. Merancang skenario tindakan perbaikan yang dikemas dalam Rencana Pelaksanaan Perbaikan Pembelajaran.

d. Mendiskusikan aspek-aspek yang diamati dengan teman sejawat.

e. Melaksanakan pembelajaran sesuai dengan rencana.

f. Mendiskusikan hasil pengamatan dengan teman sejawat.

g. Melakukan refleksi terhadap kegiatan pembelajaran yang telah dilaksanakan.

h. Konsultasi dengan supervisor.

i. Merancang tindak lanjut.

j. Re-planning, dan seterusnya, sampai mencapai batas kriteria yang telah ditetapkan. 


\section{Hasil Penelitian dan Pembahasan}

Tabel 1. Peningkatan Minat Belajar pada Siklus I dan II

\begin{tabular}{|l|l|c|c|c|}
\hline \multirow{2}{*}{ No. } & \multirow{2}{*}{ Kriteria Minat Belajar Peserta didik } & \multicolumn{3}{|c|}{ Kemunculan } \\
\cline { 3 - 5 } & & Studi awal & Siklus I & Siklus II \\
\hline 1. & Rendah & 14 & 14 & 0 \\
\hline 2. & Sedang & 2 & 3 & 5 \\
\hline 3. & Tinggi & 2 & 1 & 13 \\
\hline
\end{tabular}

Dari tabel tersebut di atas, dapat diketahui bahwa pelaksanaan perbaikan pembelajaran tentang minat belajar peserta didik pada pembelajaran Matematika mengenai pembulatan bilangan, peserta didik yang memiliki minat pada studi awal sebanyak 4 peserta didik ( 2 peserta didik yang minat sedang dan 2 peserta didik yang minat tinggi ) siklus I sebanyak 18 peserta didik ( 3 peserta didik yang minat sedang, dan 1 peserta didik yang minat tinggi ), pada siklus II sebanyak 18 peserta didik ( pada kategori tinggi dan sedang masing-masing 13 dan 5 peserta didik ). Data hasil Tes formatif yang dilaksanakan pada setiap siklus adalah sebagai berikut:

Tabel 2. Hasil Tes Formatif Siklus I dan II

\begin{tabular}{|l|l|c|c|c|}
\hline No. & \multicolumn{1}{|c|}{ Nama Peserta didik } & $\begin{array}{c}\text { Nilai Tes Formatif } \\
\text { Studi Awal }\end{array}$ & $\begin{array}{c}\text { Nilai Tes } \\
\text { Formatif } \\
\text { Siklus I }\end{array}$ & $\begin{array}{l}\text { Nilai Tes } \\
\text { Formatif Siklus } \\
\text { II }\end{array}$ \\
\hline 1. & Arif Rifalsyah & 50 & 50 & 65 \\
\hline 2. & Firman Andriyansyah & 40 & 45 & 70 \\
\hline 3. & Warni Sugiyanti & 30 & 30 & 75 \\
\hline 4. & Afifah Yulia Azzah & 30 & 30 & 65 \\
\hline 5. & Febri Dwi Puji Lestari & 20 & 25 & 65 \\
\hline 6. & Keyzza Nursafilla & 40 & 40 & 80 \\
\hline 7. & Mila Rahmadani & 30 & 30 & 75 \\
\hline 8. & Muhammad Uzzaki & 50 & 50 & 90 \\
\hline 9. & Nadin Maika Pratiwi & 40 & 45 & 100 \\
\hline 10. & Rizki Maemunah & 80 & 75 & 80 \\
\hline 11. & Ridho Fikhrian & 82 & 50 & 75 \\
\hline 12. & Shofiyur Rohman & 50 & 40 & 95 \\
\hline 13. & Wisnu Rahmadani & 40 & 50 & \\
\hline 14. & Yunita Risma Anjani & 80 & 50 & \\
\hline
\end{tabular}




\begin{tabular}{|l|l|c|c|c|}
\hline 15. & Lusiana Safara & 50 & 50 & 70 \\
\hline 16. & Fitri Widya N & 75 & 80 & 90 \\
\hline 17. & Makrifat Dika Aulia & 50 & 50 & 75 \\
\hline 18. & Faisal Paris Putra W & 50 & 50 & 85 \\
\hline & Jumlah Nilai & 887 & 915 & 1390 \\
& Nilai Rata-rata & 49,27 & 50,8 & 77,22 \\
\hline
\end{tabular}

Dari Tabel di atas dapat diketahui hasil setelah diadakan tindakan perbaikan pembelajaran pada siklus I, peserta didik yang belum tuntas (nilai di bawah 61) sebanyak 14 peserta didik, sedangkan peserta didik yang mencapai kriteria ketuntasan sebanyak 4 peserta didik. Setelah pelaksanaan tindakan perbaikan siklus II peserta didik yang mencapai tingkat ketuntasan belajar berjumlah 18 peserta didik dari jumlah 18 peserta didik kelas IV. Peningkatan hasil belajar peserta didik pada siklus I dan II dilihat pada gambar di bawah ini.

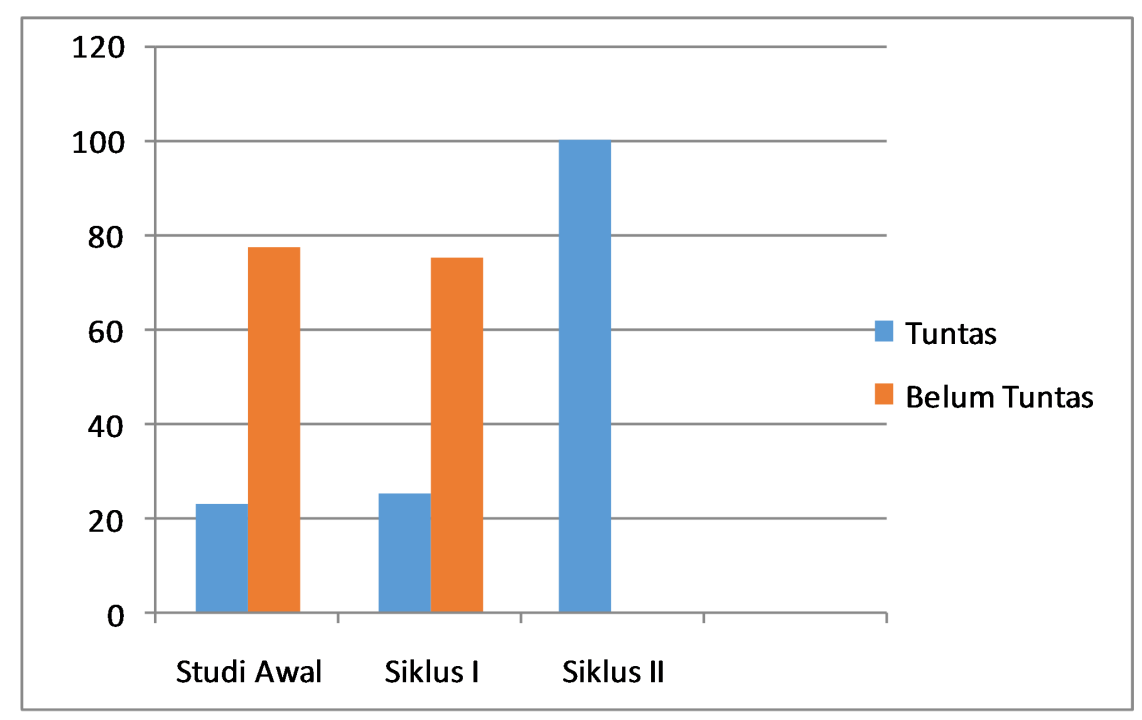

Gambar 1. Diagram Peningkatan Hasil Belajar Peserta didik pada Siklus I dan II

\section{Pembahasan Hasil Penelitian Perbaikan Pembelajaran}

\section{Siklus I}

Dari data yang diperoleh pada siklus I dapat dijelaskan sebagai berikut:

a. Tingkat minat belajar peserta didik menggunakan alat peraga lidi dan gambar nilai tempat bilangan.

Berdasarkan data hasil pengamatan dari observer, pelaksanaan tindakan perbaikan pembelajaran peserta didik dihasilkan 14 peserta didik memiliki minat belajar yang rendah, dan 4 peserta didik telah memiliki minat belajar yang baik ( $23 \%$ dari jumlah peserta didik). 
Tindakan perbaikan siklus I dapat dikatakan telah meningkatkan minat belajar peserta didik dibandingkan dengan minat belajar peserta didik pada studi awal yang hanya $20 \%$.

b. Hasil belajar peserta didik.

Pada siklus I terdapat peningkatan hasil belajar peserta didik meskipun masih terdapat 14 peserta didik yang belum tuntas belajar, karena masih berada di bawah kriteria ketuntasan minimal (KKM) yang diharapkan yaitu 61. Jika dibandingkan dengan studi awal maka dari 18 peserta didik yang belum tuntas pada studi awal, 4 peserta didik telah berhasil mencapai ketuntasan belajar minimalnya.

Berdasarkan temuan selama proses dan hasil tindakan pada siklus I, maka disusun rencana untuk melakukan tindakan perbaikan pembelajarn pada siklus II. Temuan pada siklus I yang merupakan dasar untuk pelaksanaan tindakan berikutnya adalah bahwa :

1. Tingkat motivasi belajar peserta didik menggunakan alat peraga lidi baru mencapai $82 \%$.

2. Hasil belajar yang berupa nilai, masih terdapat 14 peserta didik yang belum tuntas belajar, karena masih berada di bawah nilai ketuntasan minimal yang diharapkan.

\section{Siklus II}

Dari data yang diperoleh pada siklus I dapat dijelaskan sebagai berikut:

a. Tingkat minat belajar peserta didik menggunakan alat peraga lidi dan metode demonstrasi.

Berdasarkan data hasil pengamatan dari observer, pelaksanaan tindakan perbaikan pembelajaran peserta didik dihasilkan 5 peserta didik memiliki minat belajar yang sedang, dan 13 peserta didik telah memiliki minat belajar yang baik (94\% dari jumlah peserta didik). Tindakan perbaikan siklus II dapat dikatakan telah meningkatkan minat belajar peserta didik dibandingkan dengan minat belajar peserta didik pada siklus I.

b. Hasil belajar peserta didik.

Secara individu perbaikan pembelajaran pada siklus II telah berhasil karena seluruh peserta didik telah mencapai kriteria ketuntasan minimal sebesar 61. Jika dibandingkan dengan siklus I maka pada siklus II telah terjadi peningkatan pencapaian hasil belajar secara individu sebesar $100 \%$. Dengan demikian tindakan perbaikan pembelajaran melalui penelitian tindakan kelas dari studi awal sampai perbaikan pembelajaran siklus II yang tuntas belajar mengalami peningkatan. 


\section{Kesimpulan}

Berrdasarkan penelitian tindakan kelas ini dapat ditarik kesimpulan sebagai berikut:

1. Penggunaan model pembelajaran Demonstrasi dapat meningkatkan minat peserta didik pada mata pelajaran matematika materi pembulatan bilangan bagi peserta didik kelas IV SD Negeri 3 Purwojati semester I tahun pelajaran 2014/2015.

2. Penggunaan model pembelajaran Demonstrasi dapat meningkatkan hasil belajar mata pelajaran matematika materi pembulatan bilangan bagi peserta didik kelas IV SD Negeri 3 Purwojati semester I tahun pelajaran 2014/2015.

\section{Saran dan Tindak Lanjut}

\section{Bagi Peneliti}

a. Untuk dapat meningkatkan minat dan hasil belajar matematika pada umumnya dan pembulatan bilangan pada khusus peneliti supaya pandai dalam pemilihan metode / model dan alat peraga harus memperhatikan karakteristik matematika dan karakteristik anak sekolah dasar.

b. Penelitian ini perlu ditindak lanjuti karena hasil dari penelitian ini belum maksimal.

c. Dengan mempertimbangkan keterbatasan waktu yang tersedia hendaklah pembelajaran matematika dilaksanakan dalam bentuk pengayaan atau sebagai tugas di rumah diberikan dalam tes hendaknya jumlahnya jangan terlalu banyak.

\section{Bagi Sekolah}

a. Mengupayakan pemenuhan kebutuhan sarana dan prasarana terutama yang berupa alat peraga yang mendukung keterampilan dan meningkatkan hasil belajar.

b. Perpustakaan sekolah hendaknya menambah referensi buku-buku yang dapat dimanfaatkan peneliti-peneliti penunjang yang untuk mengadakan penelitian.

\section{Daftar Pustaka}

Abdurrahman, Mulyono. (2003). Pendidikan Bagi Anak Berkesulitan Belajar. Jakarta: Rineka Cipta.

Belly, Ellya dkk. 2006. Pengaruh Motivasi terhadap Minat Mahasiswa Akuntasi. Simposium Nasional Akuntasi 9 Padang.

Bob dan Anik Anwar. 1983. Pedoman Pelaksanaan Menuju Pra Seleksi Murni. Bandung : Ganesa Exact.

Dimyati dan Mujiono. (2006). Belajar dan Pembelajaran. Jakarta: Rineka Cipta. 
Mulyono M. 2009. Pendidikan Bagi Anak yang Berkesulitan Belajar. Jakarta : Rineka Cipta.

Mustaqim Burhan, Astuty Ary. 2008. Ayo Belajar Matematika untuk SD dan MI Kelas IV. Pusat Perbukuan Departemen Pendidikan.

Nasoetion, Andi Hakim. 1980. Landasan Matematika. Jakarta : Bharata Aksara.

Oemar Hamalik. 1993. Metode Mengajar dan Kesulitan-kesulitan Belajar. Bandung : Tarsito.

Suciati, Durri Andriani. 1997. Metode Penelitian. Jakarta : Universitas terbuka.

Sudjana, Nana. 2009. Dasar-dasar Proses Belajar Mengajar. Bandung : Sinar Baru Algensindo.

Suharsimi Arikunto. (1993). Penelitian Tindakan Kelas (PTK). Jakarta: Departemen Pendidikan dan Kebudayaan.

Suharsimi Arikunto. 1999. Prosedur Penelitian Suatu Pendekatan Politik. Jakarta Rineka Cipta.

Tim FKIP. 2013. Pemantapan Kemampuan Profesional, cet I. Tangerang Selatan : Universitas terbuka.

Tim Penyusun Kamus Pusat dan Pengembangan Bahan. 1994. Kamus Besar Indonesia. Jakarta : Balai Pustaka.

Winataputra Udin S, dkk. 2006. Strategi Belajar Mengajar cet. 19. Jakarta : Universitas terbuka. 